Journal of Primary Education
$9(5)(2020): 518-526$
UNNES
https://journal.unnes.ac.id/sju/index.php/jpe

\title{
The Relationship between Parents' Learning Motivation and Socio- Economic Status with Science Learning Achievement
}

\author{
Dwi Kodrat Krido Bangun Nugroho ${ }^{1 凶}$, Tri Joko Raharjo ${ }^{2}$, Udi Utomo ${ }^{2}$
}

DOI: https://doi.org/ 10.15294/jpe.v9i5.43239

1. SDN 2 Rawalo, Banyumas, Jawa Tengah, Indonesia

2. Pascasarjana, Universitas Negeri Semarang, Indonesia

\begin{tabular}{l} 
Article Info \\
\hline History Articles \\
Received: \\
23 September 2020 \\
Accepted: \\
19 October 2020 \\
Published: \\
31 December 2020 \\
\hline Keywords: \\
motivation to learn, \\
science learning \\
achievement, \\
socio-economic status \\
of parents
\end{tabular}

\begin{abstract}
Motivation has a strategic role in one's learning activities; besides, parents' socio-economic conditions also affect the educational process. This study aimed to find out the relationship between learning motivation and socioeconomic status of parents with science learning achievement. This research used post facto method with a quantitative research design. The research data from 85 students was taken using questionnaires and tests. Testing the instrument was done by testing the validity and reliability testing. The data analysis technique used descriptive analysis, analysis prerequisite test, hypothesis testing. The results showed a relationship between learning motivation and parents' socio-economic status that affected science learning achievement. The results of the linearity test showed that the learning motivation $\mathrm{F}_{\text {count }}$ was $0.664>0.05$, the economic status of the parents was $0.977>0.05$, so the learning motivation and economic status of the parents towards learning achievement were linear. The results of hypothesis testing using the $t$ test obtained $t$ count of 4,875 and $t$ table of 1,988 , then $t$ count $>t_{\text {table. }}$. It can be concluded that partially the motivation to learn and parents' socioeconomic status has a strong relationship with science learning achievement.
\end{abstract}

\footnotetext{
$凶$ Correspondence address:

Jl. Brigjend H.M. Bachroen, Rawalo, Pegadungan,Banyumas, Jawa

Tengah 53173

p-ISSN 2252-6404

E-mail: dwikodratkridobangunn@gmail.com 


\section{INTRODUCTION}

Efforts to improve science learning achievement require motivation as a driving force to determine good learning outcomes. Science as a subject can provide students with the opportunity to interact by using science process skills that can be used to solve problems in everyday life (Nugraha, Suyitno \& Susilaningsih, 2017). Motivation to learn is a process where needs encourage a person to carry out a series of learning activities that lead to achieving specific goals with diligent effort and mainly based on motivation, so someone who knows will produce good achievements (Utari \& Widodo, 2018). Student learning motivation needs to be improved because student learning motivation can affect learning outcomes. If students have a good motivation, student learning outcomes are also good (Eva, Muhsin \& Rozi, 2019).

Another factor influencing science learning achievement is the parents' socioeconomy, which forms the basis for children's development to succeed in learning. The number of levels (social class) between communities is relatively different depending on the economic and social conditions that exist in the community and the background interests (Anggraeni \& Setiaji, 2018). The economic situation of the parents has a considerable influence in shaping the character of the child. This financial condition is sufficient to provide wider opportunities for children to develop their potential through education. The socioeconomic conditions (SES) of parents influence parents' decision-making process in choosing quality schools for children's education (Sumarno, Stephani \& Wibowo, 2018).

Learning achievement is essentially a selfreflection of the learning effort. The better the students' learning efforts, the better the learning achievement they will get. Student achievement is influenced by various internal and external factors (Waidi, Saefudin \& Mujahidin, 2019). Effective and efficient learning does not lie in the aspects taught but is mainly due to the influence of the situations created and its methods (Utomo \& Wadiyo, 2018).

To achieve a successful and balanced life, children do not need education only from school but need help from their parents. Parents are the main educators for students when they are outside the school environment (Nugraha \& Rahman, 2017). As educators and caregivers of children, parents are required to be able to be wise in dealing with all the various children's behaviors and emotions (Lestari, 2018).

Parents direct to face a successful life; parents' role in education is very ivitalnfluential to develop knowledge, skills, and independence in every activity that results in good and successful learning achievement. Parents' role in schools is the spearhead of education in realizing educational goals as well as to deliver students to have and be able to develop their potential and competence (Nugroho \& Sudarman, 2017).

Based on the description above, it can be concluded that students who get parental guidance and attention tend to get better independence than students who do not get advice from their parents. However, the parents' problem is the socio-economic conditions, which sometimes can also affect the child's condition, which results in decreased learning motivation and has a negative impact on decreased learning achievement.

Based on the results of the initial study at Public Elementary School 2 Rawalo, Rawalo District, Banyumas Regency, it turns out that there are various types of work for the parents of students, including seventeen workers, ten entrepreneurs, three drivers, one private employee, one government employees. The diversity of work types that have implications for differences in socio-economic status is assumed to affect student learning outcomes. It is proven as an example in the science subject for class $\mathrm{V}$ in the odd semester of 2019 that the average value is only 66.2 , which is below the minimum completeness criteria set at 70 .

Based on the background description, it is very important to study the relationship between learning motivation, socio-economic status of parents, and science learning achievement. For 
this reason, it is necessary to conduct a study to examine impact of learning motivation in science learning achievement as well as to examine the relationship between parents' socioeconomic status and science learning achievement, and to examine the relationship between students' learning motivation and socioeconomic status with science learning achievement.

\section{METHODS}

This research method was a quantitative research with an ex post facto research design. The research location is in Public Elementary School 2 Rawalo, Public Elementary School 4 Rawalo, and Public Elementary School 2 Tambaknegara. This research population was the fifth-grade students of Public Elementary School Negeri in Rawalo, Banyumas, totaling 573 students. Chosen by using the Simple Random Sampling technique.

Data collection techniques with questionnaires and tests science learning achievement, before research instrument was used, the researcher tested the instrument's validity and reliability using 15 students as respondents. The results of the research instrument validity test using the Product Moment correlation formula. The variables of learning motivation, parents' socio-economic status and learning achievement tests, are declared valid if $r_{\text {value }}>r_{\text {table }}=0.532$, while the research instrument is considered reliable if the results of the analysis test show the value of the questionnaire is greater than alpha of 0.6 , the reliability test results use Alpha Cronboach formula.

The prerequisite test for data analysis was tested for normality, linearity test, and first hypothesis testing. Major hypothesis testing was continued with multiple linear regression analysis, determinant coefficient, significance test, and relative and useful contribution, then continued with minor hypothesis testing.

\section{RESULTS AND DISCUSSION}

The results of the descriptive analysis research on the relationship of parents' learning motivation and socio-economic status with the learning achievement of Public Elementary School students in class V in Rawalo District, Banyumas Regency, are as follows.

\section{Descriptive Analysis Results}

\section{Data Analysis of Learning Motivation Variables $\left(\mathrm{X}_{1}\right)$}

Descriptive analysis data of learning motivation was obtained from a questionnaire of 20 questions with two answer choices (Guttman scale). Based on the analysis results, student learning motivation in science subjects can be described in Table 1.

Table 1. Learning Motivation

\begin{tabular}{clll}
\hline \multirow{2}{*}{ Score } & Frequency & & \multirow{2}{*}{ Category } \\
\cline { 2 - 4 } & Frequency & $\%$ & \\
\hline$>19$ & 20 & 23.5 & Very high \\
$17>\mathrm{x}>18$ & 38 & 44.8 & High \\
$14>\mathrm{x}>16$ & 21 & 24.7 & Moderate \\
$11>\mathrm{x}>13$ & 5 & 5.9 & Low \\
$>10$ & 1 & 1.2 & Very low \\
Total & 85 & 100 & \\
\hline
\end{tabular}

Table 1 shows the frequency distribution of learning motivation, which is calculated from a sample of 85 students.

\section{Data Analysis of Parents' Socio-Economic Status Variables $\left(\mathrm{X}_{2}\right)$}

Descriptive analysis data of parents' socioeconomic status frequency was obtained from a 
questionnaire consisting of 15 statements with two answer choices (Guttman scale). Based on the analysis of the socio-economic status of the parents of class $\mathrm{V}$ students in Table 2 .

Table 2. Parents' Socio-Economic Status

\begin{tabular}{llll}
\hline \multirow{2}{*}{ Score } & Frequency & & \multirow{2}{*}{ Category } \\
\cline { 2 - 4 } & Frequency & $\%$ & Very high \\
\hline$>14$ & 2 & 2.4 & High \\
$12>\mathrm{x}>13$ & 18 & 21.1 & Moderate \\
$9>\mathrm{x}>11$ & 48 & 56.5 & Low \\
$6>\mathrm{x}>8$ & 16 & 18.9 & Very low \\
$>5$ & 1 & 1.2 & \\
Total & 85 & 100 & \\
\hline
\end{tabular}

Table 2 shows the frequency distribution of parents' socio-economic status in class $\mathrm{V}$, which is calculated from a sample of 85 students. The socio-economic status of the students' parents spread at all levels but on average were in an intermediate position.

\section{Data Analysis of Science Learning Achievement Variables (Y) \\ Descriptive analysis data of science learning achievement obtained from a questionnaire of 20 questions with two answer options (Guttman scale). Based on the results of the analysis of grade $\mathrm{V}$ students' science learning achievement in Table 3.}

Table 3. Science Learning Achievement

\begin{tabular}{llll}
\hline \multirow{2}{*}{ Score } & Frequency & \multicolumn{2}{c}{ Category } \\
\cline { 2 - 4 } & Frequency & $\%$ & \\
\hline$>19$ & 14 & 16.5 & Very high \\
$17>\mathrm{x}>18$ & 42 & 49.4 & High \\
$15>\mathrm{x}>16$ & 23 & 27 & Moderate \\
$12>\mathrm{x}>14$ & 5 & 6 & Low \\
$>11$ & 1 & 1.2 & Very low \\
\hline Total & 85 & 100 & \\
\hline
\end{tabular}

Table 3 shows the frequency distribution of science learning achievement for class $\mathrm{V}$ from a sample of 85 students.

Based on the descriptive analysis conducted in Public Elementary Scholl Rawalo District, Banyumas Regency with a sample of 85 students, it was found that the tendency of motivation to learn science was 38 students $(44.8 \%)$ in high category, the economic tendency of parents was 48 students (56.85\%) in medium category and for the tendency of learning achievement in science as much as 42 students $(49.5 \%)$ in high category. The results are in accordance with the research results of Wahyuni (2017) which shows that the socio-economic status of parents has a different impact on student motivation. Another research conducted by Zenni \& Margunani (2017) shows that there is an indirect influence between parents' socioeconomic conditions on learning outcomes. This indicates a significant influence between the socio-economic status of parents and achievement motivation on student achievement.

\section{Test Prerequisite Analysis Normality Test Data}

The normality test was conducted to determine whether the data on learning motivation, socio-economic status of parents, 
and student learning achievement in science were normally distributed or not. As for the normality test analysis using Chi-Square analysis, the normality test of learning motivation data was 63.176. The socioeconomic status of parents was 49.941, and the science learning achievement data was 26.682 . Thus, it can be concluded that the data distribution of the three variables is normally distributed.

\section{Linearity Test Data}

The linearity test aims to determine whether two variables have a linear relationship or not. The formula used is the F test at the 0.05 significance level. The linearity test results of learning motivation data with science learning achievement are 0.664 , and the results of the linearity test of parents' socio-economic status data with science learning achievement are 0.977. Thus, it can be concluded that parents' learning motivation and socio-economic status with science learning achievement are linear because the significance is more than 0.05 .

\section{Major Hypothesis Test \\ Multiple Linear Regression Analysis}

Multiple linear regression is used to predict the state of the dependent variable (criterion) if two or more independent variables as predictor factors are manipulated (increase and decrease the value), can be seen in Table 4 .

Table 4. Multiple Linear Regression Analysis

\begin{tabular}{|c|c|c|c|c|c|}
\hline \multirow[t]{2}{*}{ Model } & \multicolumn{2}{|c|}{$\begin{array}{l}\text { Unstandardized } \\
\text { coefficients }\end{array}$} & \multirow{2}{*}{$\begin{array}{l}\text { Standardized } \\
\text { coefficients } \\
\text { Beta }\end{array}$} & \multirow[t]{2}{*}{$\mathrm{t}$} & \multirow[t]{2}{*}{ Sig. } \\
\hline & $\mathrm{B}$ & Std. error & & & \\
\hline Constant & 4.558 & .935 & & 4.875 & .000 \\
\hline Motivation to learn $\left(\mathrm{X}_{1}\right)$ & .678 & .051 & .817 & 13.226 & .000 \\
\hline $\begin{array}{l}\text { Parents' socio-economic status } \\
\left(\mathrm{X}_{2}\right)\end{array}$ & .076 & .058 & .081 & 1.310 & .194 \\
\hline
\end{tabular}

Table 4 shows the regression coefficient. If the value of $p>0.05$, then the hypothesis is accepted. For learning motivation, it is obtained by $0.817>0.05$. The regression coefficient for parents' socio-economic status is $0.08>0.05$, so the regression coefficient is significant, so there is a relationship between learning motivation and status parents' economics on science learning achievement. The results of research is in line with the research conducted by Kambuaya (2015) which show that there is a significant influence between motivation on student achievement as indicated by the partial test with the test $(\mathrm{t})$ which obtained probability $0.003<0.05$ or the value of $t_{\text {value }}=3.201>t_{\text {table }}$ $=1.983$.

\section{Determination}

The constant $\mathrm{R}^{2}$ is used to measure the best accuracy in multiple linear regression analysis. The determinant test can be seen in Table 5.

Table 5. Determinant Test

\begin{tabular}{lllll}
\hline $\mathrm{R}$ & $\mathrm{R}$ square & Adjusted R square & $\begin{array}{l}\text { Std. error of the } \\
\text { estimate }\end{array}$ & Durbin-watson \\
\hline $.839 \mathrm{a}$ & .705 & .697 & .935 & 1.932 \\
\hline
\end{tabular}

Table 5 shows the test of determination, $\mathrm{R}$ $=0.705$, meaning that this value shows that the independent variable is getting stronger in explaining the dependent variable's variance.
The result was supporting the research conducted by Rudini (2018) which shows that the determination coefficient test was obtained 0.407, meaning that the influence of the 
independent variables (socio-economic status and learning motivation) on the dependent variable (learning outcomes) was $40.7 \%$ and the remaining $59.3 \%$ was influenced by other variables not studied.

Based on the significance test obtained, if $\mathrm{F}_{\text {value }}>\mathrm{F}_{\text {table }}$ and the significance value is below $5 \%$, then there is a positive relationship between students' learning motivation and the economic status of students' parents with learning achievement. Based on the calculation, $\mathrm{F}_{\text {value }}=$ $97.833>\mathrm{F}_{\text {table }}=3.11$, it can be concluded that there is a positive relationship between learning motivation and students' parents' economic status science learning achievement. The results were supported by research conducted by Silvia \& Wahyu (2016), which shows that the results of the significance test show that there is a significant influence between the economic conditions of the family on the science learning achievement with $\mathrm{F}_{\text {value }}=6.591$ and $\mathrm{p}=0.011$; $\mathrm{F}_{\text {table }}=3.89 ;$ then $\mathrm{F}_{\text {value }}=6.591>\mathrm{F}_{\text {table }}=3.89$ and $\mathrm{p}=0.011<0.05$.

\section{Significance}

The significance test in this study were determined by using the regression test. The significance test can be seen in Table 6 .

Table 6. Signification Test

\begin{tabular}{llllll}
\hline Model & Sum of squares & $\mathrm{df}$ & Mean square & $\mathrm{F}$ & Sig. \\
\hline Regression & 171.113 & 2 & 85.557 & 97.833 & $.000_{\mathrm{b}}$ \\
Residual & 71.710 & 82 & .875 & & \\
Total & 242.824 & 84 & & & \\
\hline
\end{tabular}

Table 6 shows the significance test if $F_{\text {value }}$ $>\mathrm{F}_{\text {table }}$ and the significance value is below 5\%. It can be concluded that there is a positive relationship between students' learning motivation and economic status with learning achievement. Based on the calculation obtained $\mathrm{F}$ value $>\mathrm{F}$ table $=97.833=3.11$, it can be concluded that there is a positive relationship between learning motivation and the economic status of students' parents with science learning achievement. The results were supported by the research conducted by Pratiwi, et al. (2018) that there is a significant relationship between motivation and learning achievement. It is obtained $r_{\text {value }}=0.151$ and $r_{\text {table }}=0.13$ at a significant level $(\alpha=0.05, \mathrm{n}=191)$, so $\mathrm{r}_{\mathrm{value}}=$ $0.151>r_{\text {table }}=0.138$, this means the calculated $r_{\text {value }}$ is significant. The significance was supported by research conducted by Setyawati \& Subowo (2018), which shows that learning motivation, family environment, and teachers' role simultaneously have a positive and significant effect on learning discipline by $60.2 \%$.

\section{Effective and Relative Contribution}

Effective contribution (SE\%) and relative contribution $(\mathrm{SR} \%)$ are used to determine and measure each variable's value. The effective contribution and relative contribution is presented in Table 7.

Table 7. Regression Coefficient and Correlation Coefficient

\begin{tabular}{|c|c|c|c|c|}
\hline Variable & $\begin{array}{l}\text { Coefficient } \\
\text { (Beta) }\end{array}$ & regression & $\begin{array}{l}\text { Correlation coefficient } \\
\left(\mathrm{r}_{\mathrm{xy}}\right)\end{array}$ & $\mathrm{R}$ square \\
\hline Motivation to learn $\left(\mathrm{X}_{1}\right)$ & .817 & & .836 & \\
\hline $\begin{array}{l}\text { Parents' Socio-Economic } \\
\text { Status }\left(\mathrm{X}_{2}\right)\end{array}$ & .081 & & .273 & .705 \\
\hline
\end{tabular}

Table 7 shows the regression coefficient (Beta) of learning motivation $=0.817$, while the correlation coefficient $\left(\mathrm{r}_{\mathrm{xy}}\right)$ of learning motivation $=0.836$. The regression coefficient (Beta) of parents' economic status $=0.081$, and the correlation coefficient $\left(r_{x y}\right)$ of the economic 
status of parents $=0.273$, with $\mathrm{R}$ Square $=$ 0.705 . The research results are supported by research conducted by Marlina (2017), which show a significant relationship between family socio-economic status and the student's lifestyle as indicated by the value of the multiple correlation coefficient $=0.545, \mathrm{~F}_{\text {value }}=22.416$. This finding is an accordance with research conducted by Rizqi \& Sumantri (2019), which shows a significant positive relationship by looking at the $\mathrm{R}$ correlation coefficient score = 0.463 and a probability value $=0.003$ and its contribution variable contributions by $21.5 \%$.

\section{Effective Contribution}

Based on the calculation results, it was found that the effective contribution (SE) of the learning motivation variable $\left(\mathrm{X}_{1}\right)$ to learning achievement (Y) was $68.3 \%$, and the effective contribution (SE) of the parents' economic status variable $\left(\mathrm{X}_{2}\right)$ to learning achievement $(\mathrm{Y})$ was $2.21 \%$. Thus, variable $\mathrm{X} 1$ has a more dominant relationship to variable $\mathrm{Y}$ than variable $\mathrm{X}_{2}$, for the total SE of $70.5 \%$. This is in line with research conducted by Santi (2009), which showed that parents' socio-economic conditions were in a low category (54.55\%).

\section{Relative Contribution}

Based on the calculation results, the relative contribution (SR) of the learning motivation variable $\left(\mathrm{X}_{1}\right)$ to learning achievement (Y) was $96.8 \%$, and the relative contribution (SR) of the parents' economic status variable
$\left(\mathrm{X}_{2}\right)$ to learning achievement $(\mathrm{Y})$ was $3.13 \%$. It can be concluded that variable $\mathrm{X}_{1}$ has a more dominant relationship to variable $\mathrm{Y}$ than variable $\mathrm{X}_{2}$ for a total $\mathrm{SR}$ of $99.93 \%$. The research results that support the research conducted by Ariyanto (2012) that learning achievement is influenced by the learning motivation factor of $37.8 \%$ and the economic level of parents by $32.9 \%$. The learning motivation and parents' economic level affect learning achievement by $55.1 \%$, and other factors influence the rest. Thus, it can be concluded that learning motivation and the economic level of parents affect learning achievement.

\section{Minor Hypothesis Test \\ Partial correlation test with t-test}

A partial correlation test is used to analyze the relationship between the independent and dependent variables jointly. The t-test correlation test can be seen in Table 8 . Table 8 shows the partial correlation coefficient using the t-test, if $t_{\text {value }}>t_{\text {table }}$, then $\mathrm{H}_{0}$ is rejected, and $\mathrm{H}_{\mathrm{a}}$ is accepted, the $\mathrm{t}_{\mathrm{value}}=4.875$ and $\mathrm{t}_{\text {table }}=$ 1.988 then $t_{\text {value }}>t_{\text {table }}$, so $H_{0}$ is rejected, and $H_{a}$ is accepted, then can conclude that learning motivation and parents' socio-economic status are partially related to science learning achievement. Supporting research results, conducted by Rizkiana (2017), shows a partially significant influence between parents' socioeconomic status, learning motivation, and learning discipline on learning achievement.

Table 8. Correlation Test

\begin{tabular}{|c|c|c|c|c|c|}
\hline \multirow[t]{2}{*}{ Model } & \multicolumn{2}{|c|}{$\begin{array}{l}\text { Unstandardized } \\
\text { coefficients }\end{array}$} & \multirow{2}{*}{$\begin{array}{l}\text { Standardized } \\
\text { coefficients } \\
\text { Beta }\end{array}$} & \multirow[t]{2}{*}{$\mathrm{t}$} & \multirow[t]{2}{*}{ Sig. } \\
\hline & $\mathrm{B}$ & Std. error & & & \\
\hline Constant & 4.558 & .935 & & 4.875 & .000 \\
\hline Motivation to learn $\left(\mathrm{X}_{1}\right)$ & .678 & .051 & .817 & 13.226 & .000 \\
\hline $\begin{array}{ll}\text { Parents' } & \text { Socio-Economic } \\
\text { Status }\left(\mathrm{X}_{2}\right) & \end{array}$ & .076 & .058 & .081 & 1.310 & .194 \\
\hline
\end{tabular}

There is a significant influence simultaneously between parents' socio-economic status, learning motivation, and learning discipline on learning achievement. Another research, namely research conducted by Saprudin, Wahjoedi \& Utami (2017), shows that from several theories and research results that have been reviewed, it shows that the existence 
of the socio-economic conditions of parents, learning motivation affects learning achievement either directly or indirectly. The discussion results show that there needs to be a role from parents and teachers in improving student achievement.

\section{CONCLUSION}

Based on the results of the research that has been done, it can be concluded that there is a relationship between learning motivation and socio-economic status of students' parents which affects the Science Learning Achievement of Class V Students in Public Elementary School Rawalo District, Banyumas Regency with an average learning motivation of $44.8 \%$ in the high category, status. Parents' socio-economic status was $56.85 \%$ in the medium category, and science learning achievement was $49.5 \%$ in the high category. It was concluded that parents' learning motivation and socio-economic status partially related to science learning achievement.

\section{REFERENCES}

Anggraeni, E. \& Setiaji. K. (2018). Pengaruh Media Sosial dan Status Sosial Ekonomi Orang Tua terhadap perilaku Konsumtif Mahasiswa. Economic Education Analysis Journal, 7(1), 172-180.

Ariyanto, S. D. (2012). Pengaruh Antara Motivasi Belajar Siswa dan Tingkat Ekonomi Orang Tua terhadap Prestasi Belajar Siswa Kelas X Jurusan Teknik Gambar Bangunan SMK Negeri 4 Semarang Tahun Ajaran 2011/2012. Scaffolding, 1(1), 61-68.

Kambuaya, C. (2015). Pengaruh Motivasi, Minat, Kedisiplinan dan Adaptasi Diri terhadap Prestasi Belajar Siswa Peserta Program Afirmasi Pendidikan Menengah Asal Papua dan Papua Barat di Kota Bandung. Share: Social Work Jurnal, 5(2), 106-208.

Lestari, E. D., Muhsin., \& Rozi, F. (2019). Pengaruh Lingkungan Keluarga, Disiplin Belajar, Kompetensi Sosial Guru, dan
Kesiapan Belajar terhadap Motivasi Belajar. Economic Education Analysis Journal, 8(1), 302-317.

Lestari, M. (2018). Hubungan pola asuh orang tua dengan kemandirian anak. Jurnal Pendidikan Anak, 8(1), 84-90.

Manalu, M. (2017). Korelasi Status Sosial Ekonomi Keluarga Terhadap Gaya Hidup Remaja di Kota Pekanbaru (Studi Kasus Siswa SMA Negeri 12 Pekanbaru). JOM FISIP, 4(2), 1-14.

Nugraha, A. \& Rahman. F. A. (2017). Strategi Kolaborasi Orang Tua dengan Konselor dalam Mengembangkan Sukses Studi Siswa. Jurnal Konseling GUSJIGANG, 3(1), 128-136.

Nugraha, A. J., Suyitno, H., \& Susilaningsih, E. (2017). Analisis Kemampuan Berpikir Kritis Ditinjau dari Keterampilan Proses Sains dan Motivasi Belajar melalui Model PBL. Journal of Primary Education, 6(1), 35-43.

Nugroho, T. A. \& Sudarma. K. (2017). Pengaruh Gaya Belajar, Motivasi Belajar, dan Kondisi Sosial Ekonomi Orang Tua Pada Hasil Belajar. Economic Education Analysis Journal, 6(1), 188-201.

Pratiwi, D., Asri, I.G.A. A. S., \& Kristiantari, M.G. R. (2018). Hubungan Motivasi Dengan Prestasi Belajar Siswa. International Journal of Elementary Education, 2(3), 192-201.

Puspitasari, Z. \& Margunani. (2017). Self Efficiacy Memediasi Pengaruh Kondisi Ekonomi Orang Tua dan Lingkungan Sekolah Terhadap Hasil Belajar Ekonomi. Economic Education Analysis Journal, 6(3), 763-776.

Rizkiana, A. (2017). Pengaruh Status Sosial Ekonomi Orang Tua, Motivasi Belajar, Disiplin Belajar Terhadap Prestasi Belajar Pada Siswa SMK Barunawati Surabaya. Jurnal Ekonomi Pendidikan dan Kewirausahaan. 2(2): 186-200.

Rizqi, A. T. \& Sumantri. M. (2019). Hubungan antara Motivasi Belajar dan Pola Asuh Orang Tua terhadap Hasil Belajar IPA. 
Jurnal Imiah Pendidikan dan Pembelajaran.3(2), 145-154.

Rudini, R. (2018). Pengaruh Status Sosial Ekonomi Orang Tua dan Motivasi Belajar terhadap Prestasi Belajar IPA Siswa Kelas X Jurusan Administrasi Perkantoran Pada Mata Pelajaran Kearsipan Di SMK Negeri 50 Jakarta (Doctoral dissertation, Universitas Negeri Jakarta).

Santi, S. D. (2009). Pengaruh Kondisi Sosial Ekonomi Orang Tua terhadap Prestasi Belajar Sosiologi Siswa Kelas XII IPS SMA N 1 Karang Tengah Kabupaten Demak Tahun Ajaran 2008/2009. Skripsi.

Saprudin, S., Wahjoedi, W., \& Widiati, U. (2017). Kondisi Sosial Ekonomi Orang Tua dan Motivasi Belajar terhadap Prestasi Belajar Ilmu Pengetahuan Sosial. Prosiding Seminar Nasional Mahasiswa Kerjasama Direktorat Jenderal Guru dan Tenaga Kependidikan Kemendikbud 2016, 17.

Setyawati, V. \& Subowo. (2018). Pengaruh Motivasi Belajar, Lingkungan Keluarga dan Peran Guru terhadap Disiplin Belajar Siswa. Economic Education Analysis Journal, 7(1), 29-44.

Sugiyono. (2013). Metode Penelitian Pendidikan Kuantitatif Kualitatif $R \& D$. Bandung: Alfabeta.

Sumarno, G., Stephani, M. R., \& Wibowo, R. 2018. Keterampilan Motorik Kasar dan
Halus Anak Usia Dini Usia 4-5 Tahun pada Kelompok Sosial Ekonomi Status Orang Tua Tingkat Menengah. Journal of Teaching Physical Education in Elementary School, 2(1), 60-65.

Utari, R. A. \& Widodo. J. (2018). Pengaruh Kepemimpinan Instruksional Guru dan Fasilitas Kelas terhadap Prestasi Belajar Siswa Melalui Motivasi Belajar. Economic Education Analysis Journal, 7(3), 10401055.

Utomo, Udi. \& Wadiyo. (2018). Pengembangan Materi Ajar Seni Budaya Sub Materi Musik pada Sekolah Umum Jenjang Pendidikan Dasar. Resital. 17 (2): 87-97.

Trisnawati, S. \& Kurniawati, W. (2016). Pengaruh Kondisi Ekonomi Keluarga Terhadap Prestasi Belajar IPA Siswa Kelas IV SD Se-Gugus 3 Kasihan Bantul. Universitas PGRI Yogyakarta. Artikel.

Wahyuni, Y. S. (2017). Analysis Of Government Policy on Education: Korelasi Tingkat Ekonomi Keluarga dengan Motivasi dan Prestasi Belajar Siswa. Jurnal Manajemen dan Pendidikan Islam. 3(1): 103-121.

Waidi., Saefudin, D. \& Mujahidin, E. (2019). Pengaruh Motivasi Keluarga terhadap Prestasi Belajar Siswa: Studi Kasus di MTs Al-Azhar Tuwel. Edukasi Islami: Jurnal Pendidikan Islam. 8(2): 207-218. 